\title{
VIABILITY OF A JEJUNAL SEGMENT AFTER NEOVASCULARIZATION BY OMENTOENTEROPEXY ${ }^{1}$
}

\author{
Mércia Maria Braga Rocha² \\ José Luiz Martins ${ }^{3}$ \\ Paulo Tubino $^{4}$ \\ Andréa Bischoff
}

\begin{abstract}
Rocha MMB, Martins JL, Tubino P, Bischoff A. Viability of a jejunal segment after neovascularization by omentoenteropexy. Acta Cir Bras [serial online] 2002 Nov-Dec;17(6). Available from URL: http://www.scielo.br/acb.
\end{abstract}

\begin{abstract}
Omentoenteropexy was developed as an alternative technique to promote neovascularization in an isolated bowel segment. Objective: The aim of the present protocol was to study the long-term viability of an isolated jejunal segment following neovascularization by omentoenteropexy. Long-term survival of a neovascularized bowel segment is an indication that the utilization of this segment as an intestinal graft can be successful. Methods: To test the proposed surgical technique, 13 Wistar rats were subjected to laparotomy, the jejunum was exposed at $20 \mathrm{~cm}$ from the angle of Treitz and a pedicle of greater omentum was isolated. An incision of $6 \mathrm{~cm}$ was made along the antimesenteric jejunal border, exposing the submucosa. Omentoenteropexy was performed between the incision of the jejunum and the pedicle of the greater omentum. After seven weeks, the mesentery of the jejunal segment subjected to omentoenteropexy was ligated and isolated from the rest of the jejunum by a complete proximal and distal transversal section. Subsequently, an end-to-end anastomosis was performed to restore the continuity of the bowel. Results: At 10 weeks from the first surgical intervention, the isolated jejunal segment subjected to omentoenteropexy was completely neovascularized and viable. Conclusion: No evidence of anatomical or functional intestinal obstruction was observed.
\end{abstract}

KEY WORDS - Omentoenteropexy. Neovascularization. Rats.

\section{INTRODUCTION}

In 1986, a study in rats showed that after maintaining an isolated bowel segment in the subcutaneous space for 30 days, all mesenteric vessels providing blood flow to this segment could be ligated without development of necrosis ${ }^{1}$.

In the last decade, two other models of bowel neovascularization (Iowa I and II) were developed.
Iowa I consists of a myoenteropexy between the internal anterior abdominal wall and the jejunal segment. Both sectioned extremities of this segment are open to the external abdominal wall as mucous fistulae. After six weeks, the mesenteric circulation to this segment is ligated without development of necrosis ${ }^{2}$. In the Iowa II technique, an isolated jejunal segment is sutured to the liver, and complete revascularization has been documented in five weeks ${ }^{3}$.

1. Trabalho realizado no Laboratório de Cirurgia Experimental da Universidade de Brasília, parte da tese de Doutorado apresentado ao Curso de Pós-Graduação em Cirurgia Pediátrica, UNIFESP-EPM.

2. Professora Adjunta-Doutora em Cirurgia Pediátrica da Universidade de Brasília - UnB.

3. Professor Adjunto-Doutor, Livre Docente Chefe do Serviço de Cirurgia Pediátrica da UNIFESP-EPM.

4. Professor Titular, Livre Docente Chefe do Serviço de Cirurgia Pediátrica da Universidade de Brasília - UnB.

5. Acadêmica de Medicina do sexto ano da Universidade de Brasília - UnB. 
In 1994, omentoenteropexy was developed as an alternative technique of intestinal neovascularization. The advantages of utilizing the omentum for neovascularization include better mobility and less vulnerability to damage than host organs previously utilized in similar techniques ${ }^{4,5}$. In addition, it has been suggested that the greater omentum has the ability to induce or mediate angiogenesis through certain lipid angiogenic factors ${ }^{6}$.

The aim of the present study is to assess the longterm viability of neovascularization in a jejunal segment using the omentoenteropexy technique.

\section{METHODS}

Thirteen adult male Wistar rats, weighing from 225 to $260 \mathrm{~g}$ were studied. Following $5 \mathrm{~h}$-fasting, the animals were anesthesized by I.M. injection of chloral hydrate ketamine $(10 \mathrm{mg} / \mathrm{kg})$ and chloral hydrate xylasine $2 \%(1.0 \mathrm{mg} / \mathrm{kg})$, and a $5 \mathrm{~cm}$-incision in the midline of the abdominal anterior wall was carried out under aseptic conditions. Subsequently, a pedicle of greater omentum was isolated, and a jejunal segment at $20 \mathrm{~cm}$ from the angle of Treitz was subjected to a 6 $\mathrm{cm}$-incision along its antimesenteric border to expose the submucosa. Omentoenteropexy was then performed with a polypropylene $6-0$ uninterrupted sutures between the jejunal incision and the pedicle of the greater omentum.

After seven weeks, the animals underwent another laparotomy and the mesentery of the jejunal segment subjected to omentoenteropexy was ligated (silk 3-0 suture) and excised from the jejunum by complete transverse proximal and distal section. Subsequently, an end-to-end anastomosis between the neovascularized jejunal segment (NJS) and the normal jejunum was performed with polypropylene 6-0 sutures to restore the continuity of the bowel (Figure 1).

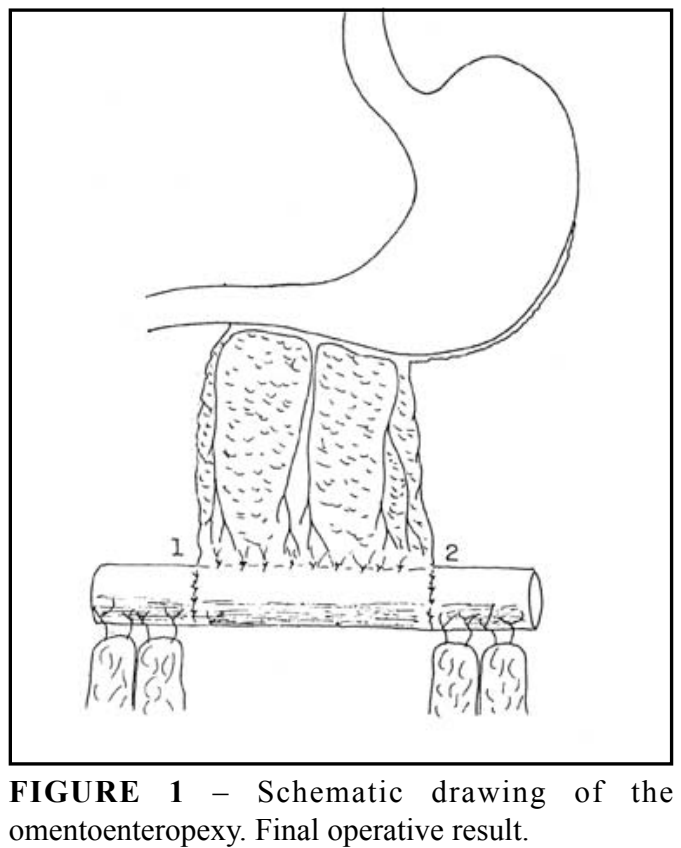

After ten weeks from the first surgical intervention, a third laparotomy was performed to inspect the NJS for viability and anatomical alterations. During this procedure, specimens for anatomopathological examination were collected from the NJS (c), at $2 \mathrm{~cm}$ proximal to jejunum (a), at $2 \mathrm{~cm}$ distal to NJS (e) and at the anastomotic zones (b and d). H\&E histological staining was utilized to study the neovascularized areas. The diameter of all segments was measured and the entire proximal and distal jejunal segment diameters were compared using Friedman's t test. The present protocol was approved by the EPM (Escola Paulista de Medicina) Laboratory Animal Use Committee.

\section{RESULTS}

A macroscopic examination of the jejunal segment subjected to omentoenteropexy revealed no signs of necrosis or anastomotic stenosis. All intestinal segments involved in this surgical procedure appeared viable and healthy (Table 1), and maintained normal peristalsis. The NJS showed a larger diameter in comparison with the proximal and distal jejunum $(\mathrm{p}<0.05$; Table 2$)$. Proliferation of blood vessels was evident in the area subjected to omentoenteropexy. 
TABLE 1 - Intestinal diameters.

\begin{tabular}{cccccc}
\hline Rat & $\mathbf{a}(\mathbf{c m})$ & $\mathbf{b}(\mathbf{c m})$ & $\mathbf{c}(\mathbf{c m})$ & $\mathbf{d}(\mathbf{c m})$ & $\mathbf{e}(\mathbf{c m})$ \\
\hline $\mathbf{1}$ & 0.70 & 0.70 & 0.80 & 0.70 & 0.70 \\
$\mathbf{2}$ & 0.50 & 0.90 & 0.90 & 0.50 & 0.50 \\
$\mathbf{3}$ & 0.60 & 0.80 & 0.70 & 0.50 & 0.50 \\
$\mathbf{4}$ & 0.52 & 0.60 & 1.30 & 0.80 & 0.50 \\
$\mathbf{5}$ & 1.20 & 1.20 & 1.60 & 1.30 & 1.20 \\
$\mathbf{6}$ & 1.00 & 2.00 & 2.00 & 1.00 & 0.60 \\
$\mathbf{7}$ & 0.50 & 0.50 & 0.90 & 0.50 & 0.40 \\
$\mathbf{8}$ & 0.64 & 0.54 & 0.70 & 0.80 & 0.60 \\
$\mathbf{9}$ & 1.00 & 1.00 & 1.00 & 1.00 & 0.90 \\
$\mathbf{1 0}$ & 0.45 & 0.45 & 0.70 & 0.70 & 0.50 \\
$\mathbf{1 1}$ & 0.43 & 0.50 & 0.60 & 0.60 & 0.44 \\
$\mathbf{1 2}$ & 1.00 & 0.80 & 1.50 & 1.04 & 0.80 \\
$\mathbf{1 3}$ & 0.60 & 0.70 & 0.90 & 0.70 & 0.70 \\
\hline
\end{tabular}

cm: centimeters; a: proximal segment; b: proximal anastomosis; c: NJS; d: distal anastomosis; e: distal segment.

TABLE 2 - Intestinal diameters ( $a, b, c, d, e)$.

\begin{tabular}{ccccccc}
\hline $\begin{array}{c}\text { Intestinal } \\
\text { segment }\end{array}$ & a (SE) & b (SE) & c (SE) & d (SE) & e (SE) & $\begin{array}{c}\text { Friedman's } \\
\text { test }\end{array}$ \\
\hline $\begin{array}{c}\text { Diameter } \\
(\mathbf{m m})\end{array}$ & 0.70 & 0.82 & $1.05^{*}$ & 0.78 & 0.64 & $<0.001^{*}$ \\
\hline
\end{tabular}

SE: standart error. mm: milimeter. a: proximal segment; b: proximal anastomosis; c: NJS; d: distal anastomosis; e: distal segment.

* level of statistical significance

\section{DISCUSSION}

Neovascularization techniques in isolated bowel segments have been widely studied. The utilization of the greater omentum as a vascular pedicle in bowel elongation has been previously studied, but the sectioned intestinal segment was not re-anastomosed into the gastrointestinal system ${ }^{4,6}$. In addition, assessment of viability was performed at two days following ligation of the neovascularized bowel mesentery ${ }^{7}$. In the Iowa I and Iowa II models, viability of the neovascularized bowel and absence of necrosis were examined at 6 and 5 weeks respectively ${ }^{2,3}$ In contrast, in our present study the presence of viable neovascularization and absence of necrosis in the jejunal segment were assessed at 10 weeks. Furthermore, because the jejunal segment was re-anastomosed into the intestinal tract, we were able to perform anatomical and functional analysis of the bowel. Motility and absorption capability of an NJS have been previously examined by other investigators $^{8}$. However, this is the first time, to our knowledge, that a long-term functional and anatomical assessment of a neovascularized jejunal segment has been performed.

In the present study the NJS was evaluated 10 weeks after the neovascularization procedure to assure that a normal intestinal motility was restored. The extrinsic NJS innervation was completely disrupted when its mesentery was ligated and isolated and the proximal and distal intestine were sectioned. It is possible that the disrupted innervation has contributed to an increase in NJS diameter. However, this anatomical alteration did not result in functional bowel obstruction.

\section{CONCLUSION}

A neovascularized jejunal segment was viable and with no signs of necrosis at 10 weeks following omentoenteropexy procedure. No functional or anatomical intestinal obstruction was observed using this technique. 


\section{ACKNOWLEDGMENTS}

We thank Elizabete Joaquim dos Santos and José Tavares dos Santos, for technical support. We thank Dr. Sonia Doe for language support.

\section{REFERENCES}

1. Cohen BE, Barrera A. Survival of transferred intestinal segments after vascular pedicle interruption. Plast Recontr Surg 1987;79: 610-5.

2. Ienaga T, Kimura K, Hashimoto K, Lee SC, Braskstad M, Soper R. Isolated bowel segment (Iowa model 1). J Pediatr Surg 1990;25: 902-4

3. Yamazoto H, Kimura K, Yoshino H, Soper RT. The isolated bowel segment (Iowa model II): created in functioning bowel. J Pediatr Surg 1991;26:780-3.
4. Shoshany G, Cohenn E, Mordohovich D, Hayari L, Harshai Y, Bar-maor J. Creation of the isolated bowel segment in animal by omentoenteropexy. J Pediatr Surg 1994;29:1344-7.

5. Shoshany G, Mordohovich D, Lichtig H, Bar-Maor JA. Preserved viability of the isolated bowel segment created by omentopexy: a histological observation. J Pediatr Surg 1995; 30:1291-3.

6. Goldsmith HS, Griffith AL, Kupferman A, Catsimpoolas N. Lipid angiogenic factor from omentum. J Am Med Assoc 1984;252:2034-6.

7. Fu T, Wang $\mathrm{X}, \mathrm{Xu}$ M. Bowel elongation technique by using omentum as vascular pedicle in beagle dogs. Chung Kuo Hsiu Chung Chien Wai Ko Tsa Chih 1997;11:106-8.

8. Shoshany G, Diamond E, Mordohovich D, Bar-Maor JA. Jejunal mucosal function of the isolated bowel segment created by omentoenteropexy in dogs: a study by in situ luminal perfusion. J Pediatr Surg 1995;30:402-5.

Rocha MMB, Martins JL, Tubino P, Bischoff A. Viabilidade de segmento jejunal neovascularizado por omentoenteropexia. Acta Cir Bras [serial online] 2002 Nov-Dez;17(6). Disponível em URL: http://www.scielo.br/acb.

RESUMO - A omentoenteropexia foi desenvolvida como uma alternativa para técnica de neovascularização em segmentos intestinais isolados, evidenciando algumas vantagens em relação a utilização de órgãos previamente descritos. Objetivo: Avaliar a viabilidade de um segmento jejunal neovascularizado por omentoenteropexia. Métodos: Treze ratos Wistar foram submetidos a laparotomia, com exposição do jejuno vinte centímetros após o ligamento de Treitz e obtenção de um pedículo de omento. Na borda antimesentérica do jejuno foi feita uma incisão de seis centímetros com exposição da submucosa intacta. A omentoenteropexia foi confeccionada na região incisada do jejuno e no pedículo do omento. Após sete semanas, foi realizada uma nova laparotomia e o mesentério do segmento jejunal com omentoenteropexia foi suturado e excisado. Foi realizada secção transversal completa, proximal e distal, sendo isolado o segmento jejunal. Confeccionada anastomose término-terminal entre o jejuno neovascularizado e o jejuno com vascularização normal para restaurar a continuidade do trânsito intestinal. Resultados: Não foi observada necrose em nenhum dos segmentos jejunais submetidos a omentoenteropexia. Todos segmentos apresentavam peristalse contínua. Foi observada neovascularização na porção do omento suturada ao jejuno. Conclusão: O segmento jejunal submetido a neovascularização por omentoenteropexia estava viável após dez semanas e não foram observados sinais de obstrução funcional.

DESCRITORES - Omentoenteropexia. Neovascularização. Ratos.

Address for correspondence:

Conflito de interesse: nenhum

Dr. Mércia M.B. Rocha

Fonte de financiamento: nenhuma

SHIS QL, 06 conjunto 02 , casa 08

71620-025 Brasília - DF

Data do recebimento: $25 / 09 / 2002$

Data da revisão: $10 / 10 / 2002$

Data da aprovação: 30/10/2002 